\title{
Sunroot mediated synthesis and characterization of silver nanoparticles and evaluation of its antibacterial and rat splenocyte cytotoxic effects
}

This article was published in the following Dove Press journal:

International Journal of Nanomedicine

II March 2015

Number of times this article has been viewed

\author{
Adithan Aravinthan ${ }^{1, *}$ \\ Muthusamy Govarthanan ${ }^{2,3, *}$ \\ Kandasamy Selvam ${ }^{4}$ \\ Loganathan Praburaman ${ }^{2,3}$ \\ Thangasamy Selvankumar ${ }^{3}$ \\ Rangachari Balamurugan' \\ Seralathan Kamala-Kannan ${ }^{2}$ \\ Jong-Hoon Kim' \\ 'College of Veterinary Medicine, \\ Biosafety Research Institute, Chonbuk \\ National University, Jeonju, South Korea; \\ 2Division of Biotechnology, Advanced \\ Institute of Environment and Bioscience, \\ College of Environmental and Bioresource \\ Sciences, Chonbuk National University, \\ Iksan, South Korea; ${ }^{3} \mathrm{PG}$ and Research \\ Department of Biotechnology, Mahendra \\ Arts and Science College, Kalippatti, \\ Namakkal,Tamil Nadu, India; ${ }^{4}$ Centre for \\ Biotechnology, Muthayammal College \\ of Arts and Science, Rasipuram, Namakkal, \\ Tamil Nadu, India \\ *These authors contributed equally to this \\ work
}

Correspondence: Seralathan

Kamala-Kannan

Division of Biotechnology, Advanced

Institute of Environment and

Bioscience, College of Environmental

and Bioresource Sciences, Chonbuk

National University, Iksan 570-752,

South Korea

Tel +82638500842

Fax +82 638500834

Email kannan@jbnu.ac.kr

Jong-Hoon Kim

College of Veterinary Medicine, Biosafety

Research Institute, Chonbuk National

University, Jeonju 56I-756, South Korea

Tel +821062077180

Fax +826378500923

Email jhkim I@jbnu.ac.kr
Abstract: A rapid, green phytosynthesis of silver nanoparticles (AgNPs) using the aqueous extract of Helianthus tuberosus (sunroot tuber) was reported in this study. The morphology of the AgNPs was determined by transmission electron microscopy (TEM). Scanning electron microscopy-energy-dispersive spectroscopy (SEM-EDS) and X-ray powder diffraction (XRD) analysis confirmed the presence of AgNPs. Fourier transform infrared spectroscopy (FTIR) analysis revealed that biomolecules in the tuber extract were involved in the reduction and capping of AgNPs. The energy-dispersive spectroscopy (EDS) analysis of the AgNPs, using an energy range of 2-4 keV, confirmed the presence of elemental silver without any contamination. Further, the synthesized AgNPs were evaluated against phytopathogens such as Ralstonia solanacearum and Xanthomonas axonopodis. The AgNPs (1-4 mM) extensively reduced the growth rate of the phytopathogens. In addition, the cytotoxic effect of the synthesized AgNPs was analyzed using rat splenocytes. The cell viability was decreased according to the increasing concentration of AgNPs and $67 \%$ of cell death was observed at $100 \mu \mathrm{g} / \mathrm{mL}$.

Keywords: cytotoxicity, Helianthus tuberosus, nanobiotechnology, phytosynthesis, splenocytes

\section{Introduction}

Nanobiotechnology is a promising interdisciplinary field of biotechnology and nanoscience that offers novel nanoscale materials with interesting applications in different scientific fields such as medicine, biotechnology, chemistry, physics, and material sciences. ${ }^{1,2}$ Metallic nanoparticles are attractive due to their potential applications in novel technologies. ${ }^{3}$ Among the metallic nanoparticles, silver nanoparticles (AgNPs) have attracted the attention of researchers in the field of science and technology due to their vast biological applications. Several studies have reported the synthesis of AgNPs by physicochemical methods. ${ }^{4,5}$ The chemical synthesis of AgNPs may lead to the presence of some toxic chemicals on the surface that may have adverse effects in its application. Also, the chemical used in the synthesis may pollute the environment. ${ }^{6}$ Hence, there is an urgent need to develop eco-friendly biological methods of AgNPs synthesis instead of using toxic chemicals.

Nowadays, biological synthesis of AgNPs has been proposed as an emerging technology, and offers several advantages compared to conventional methods. Several studies reported AgNPs synthesis using biological materials, such as microorganisms, plant extracts, milk, and panchakavya. ${ }^{7-10}$ Phytosynthesis of AgNPs using plant materials has an edge over microbial mediated synthesis owing to their immediate and large-scale production. ${ }^{11,12}$ Thus, considerable attention is given to exploit the 
synthesis of AgNPs using plant-based products. Several studies reported on the synthesis of AgNPs using various plant extracts. ${ }^{13-15}$ It has been established that proteins present in the plant extracts were involved in the reduction of $\mathrm{Ag}^{+}$ions to nanocrystallites. Helianthus tuberosus L., a perennial herb, is a species of sunflower native to eastern North America and widely cultivated across the temperate zone for its edible tuber. Extracts of $H$. tuberosus L. tubers are aperient, cholagogue, and diuretic and have long been used in folk medicine to treat stomach problems, diabetes, and rheumatism. ${ }^{16,17}$ However, to our knowledge, the sunroot (H. tuberosus L.) tuber extract has never been used for the synthesis of AgNPs.

In vitro cytotoxicity study is an important assay to evaluate the mechanisms of toxicity caused by nanoparticles. AgNP-induced toxicity is related with mitochondrial damage, oxidative stress, DNA damage, and induction of apoptopsis. ${ }^{18}$ Previous studies reported the cytotoxicity of AgNPs against NIH 3 T3 fibroblast cells, HeLa cells, human glioblastoma cells, and human breast cancer cells (MCF-7). ${ }^{19-22}$ However, to our knowledge, cytotoxicity of AgNPs in rat splenocytes have never been explored.

Plant disease control is an important requirement for agriculture in the 21 st century. Microorganisms are associated with several devastating diseases in economically important crops worldwide. Phytopathogenic bacteria cause enormous problems in agriculture, resulting in severe economic losses, since plants are the main nutrient sources of these pathogens..$^{23}$ Ralstonia solanacearum and Xanthomonas axonopodis are the most extensively studied phytopathogens in potato (Solanum tuberosum), tobacco (Nicotiana tabacum), and tomato (Lycopersicon esculentum) plant systems. The increasing population of these phytopathogens causes degradation of the occluded xylem vessels and the death of the plants. Hence, the synthesis of AgNPs and their antibacterial properties are emerging as fields of great interest among researchers. Hence, the objectives of the present study were (i) to synthesize AgNPs using H. tuberosus tuber extract, (ii) to characterize the synthesized AgNPs, and (iii) to assess the cytotoxicity of AgNPs synthesis against freshly isolated rat splenocytes, and (iv) to evaluate the bactericidal activities of the synthesized AgNPs.

\section{Materials and methods \\ Plant material}

The dried tuber of $H$. tuberosus was purchased from a local shop in Iksan, South Korea. One kilogram of tuber powder was soaked in $2.5 \mathrm{~L}$ methanol for 78 hours with occasional stirring. The solvent was removed by using Rotovac below $70^{\circ} \mathrm{C}$. The solvent-free aqueous extract was used for the synthesis of AgNPs.

\section{Synthesis of AgNPs}

Silver nitrate $\left(\mathrm{AgNO}_{3}\right)$ was purchased from Sigma-Aldrich (St Louis, MO, USA) and the synthesis of AgNPs was carried out according to Lee et al. ${ }^{8}$ Briefly, $4 \mathrm{~mL}$ of the extract was mixed with $96 \mathrm{~mL}$ of $1 \mathrm{mM} \mathrm{AgNO}_{3}$ solution and the resulting greenish white mixture was incubated for 8 hours in a rotary shaker $(200 \mathrm{rpm})$ at $26^{\circ} \mathrm{C}$. The reduction of $\mathrm{Ag}^{+}$ions to $\mathrm{Ag}$ nanocrystals was monitored by the change in the color of the reaction mixture from greenish white to dark brown.

\section{Characterization of AgNPs}

The morphology of the synthesized AgNPs was examined using transmission electron microscopy (Bio-TEM) (H-7650; Hitachi Ltd., Tokyo, Japan). The elemental composition of the synthesized AgNPs was confirmed by scanning electron microscopy-energy-dispersive spectra (SEM-EDS) (JEOL-64000; Tokyo, Japan). The X-ray powder diffraction (XRD) was carried out using Rigaku X-ray diffractometer (Rigaku, Japan). The scanning was performed in the region of $2 \theta=30^{\circ}-80^{\circ}$ at $0.041^{\circ} / \mathrm{min}$ with a time constant of 2 seconds. The Fourier transform infrared spectrum (FTIR) of the AgNPs was obtained on a PerkinElmer FTIR spectrophotometer (Waltham, MA, USA) in the diffuse reflectance mode at a resolution of $4 \mathrm{~cm}^{-1}$ in $\mathrm{KBr}$ pellets.

\section{Antibacterial activity of AgNPs}

The phytopathogenic bacterial strains $R$. solanacearum and $X$. axonopodis were procured from the Korean Agriculture Culture Collection (KACC), South Korea. The freshly cultured bacterial strains from the Luria-Bertani (LB) agar plates were inoculated into LB broth and incubated at $37^{\circ} \mathrm{C}$ in a shaking incubator. After appropriate growth, the cultures were used for further experiments. The cultures were allowed to grow in $100 \mathrm{~mL}$ of LB broth containing the synthesized AgNPs at different concentrations in the range 1-4 mM. The optical density was measured every 4 hours to determine the growth of the bacteria using the Shimadzu UV-1800 spectrophotometer. The culture without AgNPs was used as a control.

\section{Isolation and propagation of rat splenocytes}

Adult (Sprague dawley, 8-12 week old) rats were purchased from Koatech, South Korea. The rats were maintained in a specific pathogen-free facility. Fresh splenocytes of the rat was obtained by teasing the spleen under aseptic 
conditions according to Lu et al. ${ }^{24}$ Single-cell suspensions were prepared from rat spleen by pressing the tissues through a sterile wire mesh and washing the cells in Roswell Park Memorial Institute (RPMI) medium containing 1\% antibiotic (Anti-Anti; Gibco, South Korea). The animal experiments were carried out in accordance with the institutional animal care and use committee at Chonbuk National University.

\section{3-(4,5-dimethylthiazol-2-yl)-2,5- diphenyltetrazolium bromide assay}

The isolated rat splenocytes were treated with series of $10-100 \mu \mathrm{g} / \mathrm{mL}$ of phytosynthesized AgNPs in 96-well tissue culture plates. The treated cells were incubated for 24 hours at $37^{\circ} \mathrm{C}$ with $5 \% \mathrm{CO}_{2}$ for cytotoxicity analysis. The cells were then subjected to 3-(4,5-dimethylthiazol-2-yl)2,5-diphenyltetrazolium bromide (MTT) assay. The stock concentration $(5 \mathrm{mg} / \mathrm{mL})$ of MTT, a yellow tetrazole, was prepared and $20 \mu \mathrm{L}$ of MTT was added in each AgNP-treated well and incubated for 4 hours. Purple colored formazan crystals were observed in the bottom of the well and these crystals were dissolved with $200 \mu \mathrm{L}$ of dimethyl sulfoxide (DMSO), and read at $595 \mathrm{~nm}^{18,22}$ in a multi-well plate reader (Epoch microplate spectrophotometer; Biotek, Winooski, USA).

\section{Results and discussion Characterization studies}

The addition of the tuber extract to $1 \mathrm{mM}$-solution of $\mathrm{AgNO}_{3}$ changed the color from greenish white to dark brown in about 1 hour. The intensity of the color increased after 8 hours of incubation and the reduction of pure $\mathrm{Ag}^{+}$ions to $\mathrm{Ag}^{0}$ was monitored by measuring the $\mathrm{UV}-\mathrm{V}$ is spectrum of the reaction media (Figure 1). The UV-Vis spectra of the silver surface plasmon resonance band occurs near $430 \mathrm{~nm}$. Previous studies

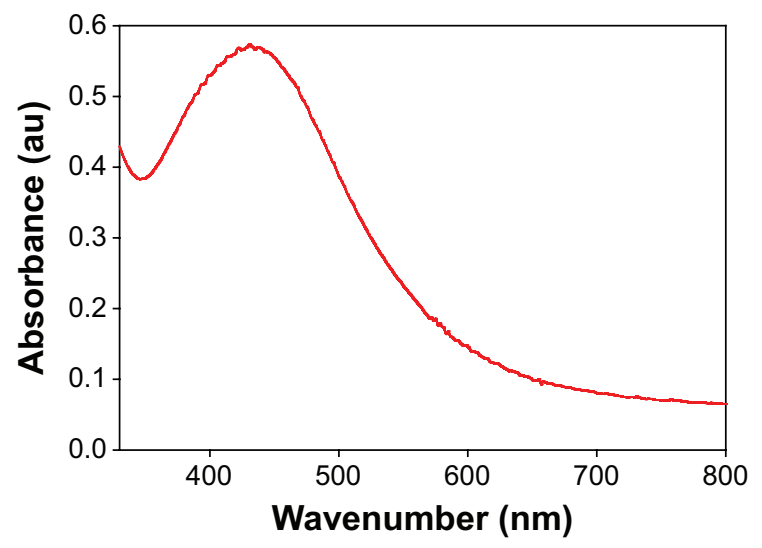

Figure I UV-Vis absorption spectrum of the AgNPs prepared from I $\mathrm{mM} \mathrm{AgNO}_{3}$ solution.

Abbreviation: AgNPs, silver nanoparticles.

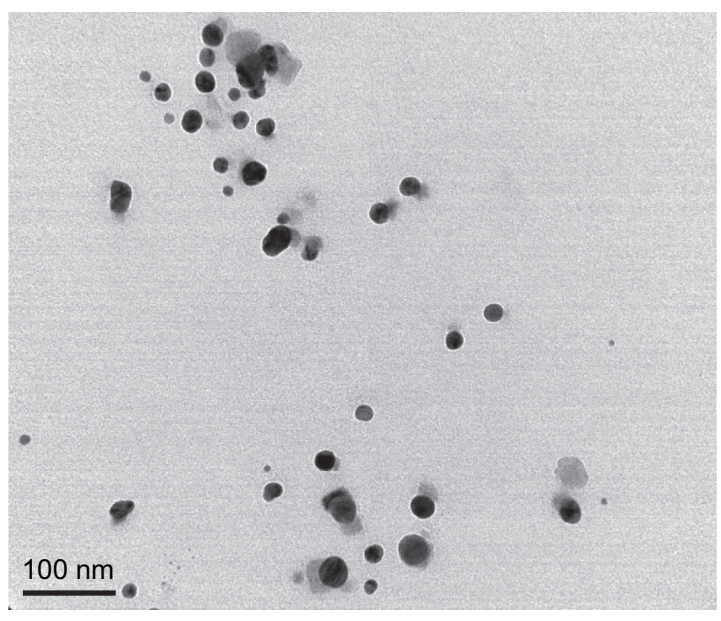

Figure 2 TEM image of AgNPs.

Abbreviations: TEM, transmission electron microscopy; AgNPs, silver nanoparticles.

have reported the presence of AgNPs exhibiting yellowish brown color in solution due to the excitation of surface Plasmon vibrations. ${ }^{25,26}$ However, the color change was not observed in the control flask. The biomolecules present in the tuber extract may reduce the Ag ions present in the solution. This was supported by the results from FTIR studies where stretching vibrations of amines, alkanoids, and alkaloids were observed.

The morphology and size of the phytosynthesized AgNPs were observed by TEM images (Figure 2). The particles were spherical in shape, monodisperse, and the size of the particles varied from 10-70 $\mathrm{nm}$. To confirm the presence of Ag, the samples were analyzed in SEM-EDS, and the results are shown in Figure 3. The results showed strong silver signals ( $3 \mathrm{keV}$ ), along with weak oxygen and carbon peaks, which might have originated from the tuber extract. The results are

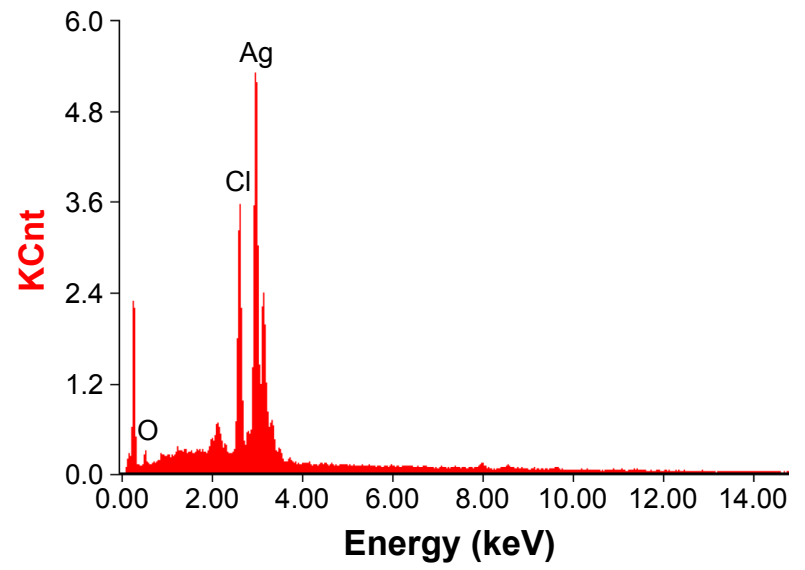

Figure 3 SEM-EDS spectrum of AgNPs. A strong peak at $3 \mathrm{keV}$ confirms the presence of $\mathrm{Ag}$.

Abbreviations: SEM-EDS, scanning electron microscopy-energy-dispersive spectroscopy; AgNPs, silver nanoparticles. 


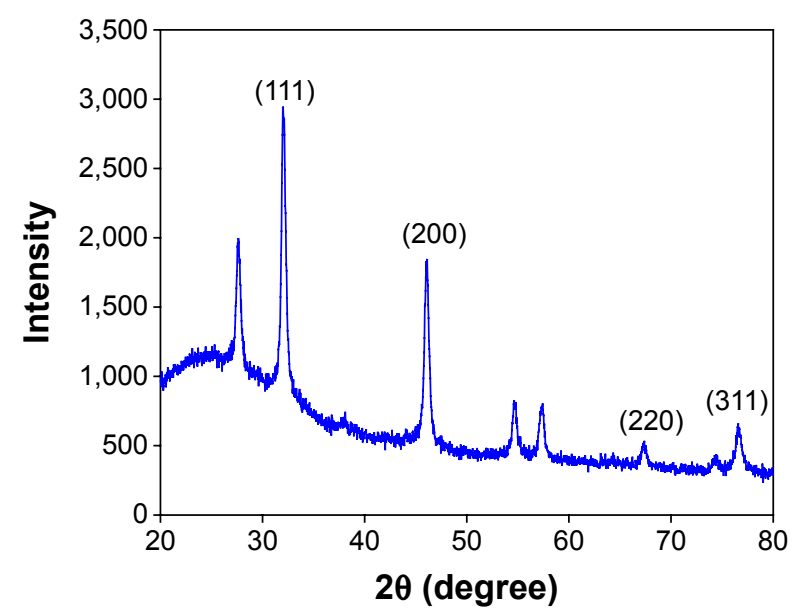

Figure 4 XRD pattern of AgNPs synthesized using tuber extract. Abbreviations: XRD, X-ray powder diffraction; AgNPs, silver nanoparticles.

consistent with previous studies that reported the strong peak for AgNPs at $3 \mathrm{keV} .^{7,8}$ The EDS quantitative analysis showed the presence of silver (100\%) without any contaminants.

$\mathrm{XRD}$ was used for the identification of the crystal nature of the AgNPs. The XRD patterns of the synthesized AgNPs are shown in Figure 4. The peaks at $2 \theta$ values of 38, 46, 67.4 , and 78 correspond to $111,200,220$, and 311 , indicating the cubic nature of AgNPs. The results are in agreement with several studies that reported the cubic nature of biologically synthesized AgNPs. ${ }^{27,28}$ The FTIR spectrum of the AgNPs is shown in Figure 5. Some pronounced peaks were observed at $3,329,2,941,1,759,1,067$, and $731 \mathrm{~cm}^{-1}$ in the $4,000-400 \mathrm{~cm}^{-1}$ region. The corresponding peaks were associated with the stretching vibrations of $-\mathrm{C}-\mathrm{O}$, $\mathrm{C}-\mathrm{H}, \mathrm{C}=\mathrm{C}, \mathrm{CH}_{2}$, and $\mathrm{O}-\mathrm{H}$, respectively. The absorbance

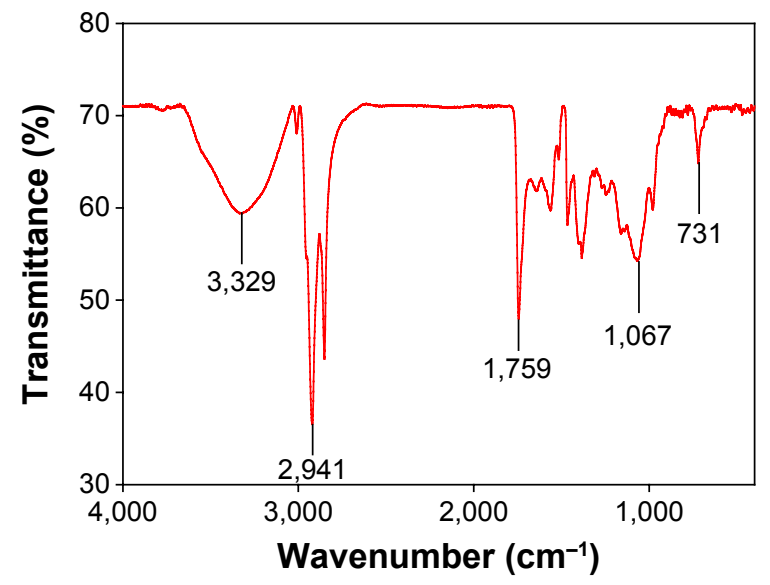

Figure 5 FTIR spectra of AgNPs synthesized using tuber extract. Abbreviations: FTIR, Fourier transform infrared spectroscopy; AgNPs, silver nanoparticles. peaks could be attributed to the phytochemicals present in the tuber extract, such as reducing sugars, flavonoids, saccharides, and proteins. ${ }^{29}$ Pan et $\mathrm{a}^{16}$ reported the presence of coumarins, unsaturated fatty acids, and phenols in the H. tuberosus extract.

\section{Antibacterial activity}

Numerous studies reported that biologically synthesized AgNPs have significant antibacterial and antifungal activities, and could be used for the treatment of bacterial and fungal diseases in biotic communities. ${ }^{78}$ However, the adverse effects of AgNPs need to be carefully evaluated before they could be used in antimicrobial products. Hence, phytosynthesized AgNPs were studied for antibacterial activity against phytopathogenic bacteria, namely, $R$. solanacearum and $X$. axonopodis. The bacterial growth measurements at different concentrations ( $1-4 \mathrm{mM}$ ) of the AgNPs were determined 0-24 hours at regular time intervals (Figure 6A and B). The observed results indicated that $4 \mathrm{mM}$ concentrations of the AgNPs effectively encountered the bacterial population
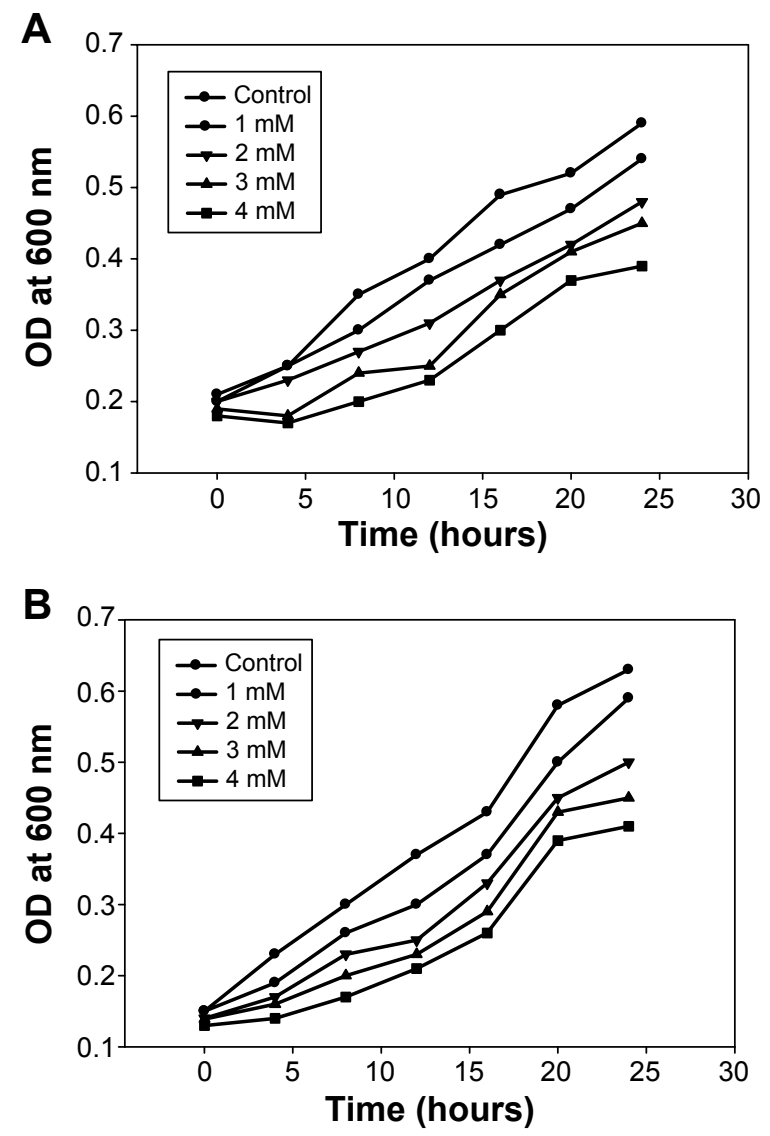

Figure 6 Effect of AgNPs on growth of phytopathogenic bacteria. Notes: (A) Ralstonia solanacearum and (B) Xanthomonas axonopodis. Abbreviation: AgNPs, silver nanoparticles. 
in the medium. The results are consistent with our previous study reporting the antibacterial activity of AgNPs against antibiotic resistant strains. ${ }^{7}$

\section{Cytotoxicity}

The cytotoxic potential of the biologically synthesized AgNPs was assessed using MTT assay. Figure 7A shows the viability of splenocytes with the increasing concentration
$(10-100 \mu \mathrm{g} / \mathrm{mL})$ of AgNPs, and the reduction of color compared to untreated cells observed at $595 \mathrm{~nm}$ revealed the cytotoxicity. Thus, in vitro cytotoxicity of the AgNPs was evaluated against rat splenocytes at different concentrations $(10,20,40,80$ and $100 \mu \mathrm{g} / \mathrm{mL})$, and the results are shown in Figure 7B. The results clearly demonstrated that the splenocytes viability was directly proportional to the concentration of the AgNPs. The cell death (10\%) was
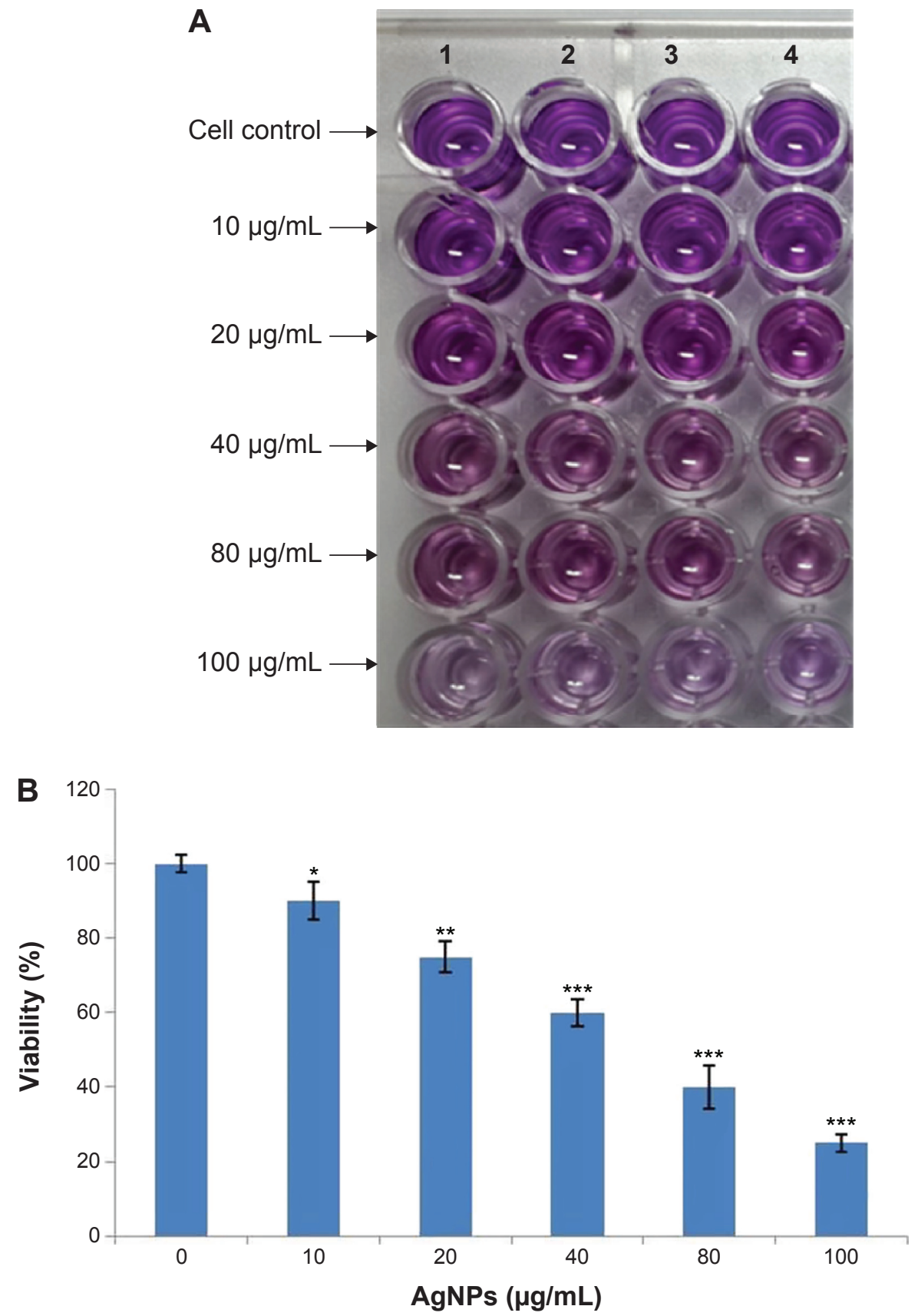

Figure 7 Cytotoxic effect of AgNPs on growth of rat splenocytes.

Notes: (A) a 96-well plate image of MTT assay, the toxicity is indicated by color reduction; (B) dose dependent reduction of cell viability at $595 \mathrm{~nm}$. $* P<0.05$; $* * P<0.0$ I; $* * * P<0.001$. Abbreviation: AgNPs, silver nanoparticles. 
reported at $10 \mu \mathrm{g} / \mathrm{mL}$ and gradually increased according to the concentration and reached the maximum (67\%) at 100 $\mu \mathrm{g} / \mathrm{mL}$. Hackenberg et $\mathrm{al}^{30}$ reported that $10 \mu \mathrm{g} / \mathrm{mL}$ of AgNPs reduced human mesenchymal stem cells viability within 1 hour exposure. Vivek et $\mathrm{al}^{22}$ reported that the cytotoxicity of AgNPs was significantly increased according to the concentration of nanoparticles. Moreover, several studies reported that AgNPs may induce reactive oxygen species and cause damage to cellular components leading to cell death. ${ }^{31-33}$

\section{Conclusion}

To the best of our knowledge, this is the first study to report the synthesis of AgNPs using $H$. tuberosus tuber extract. The proposed method is a simple, green, and cost-effective method for the synthesis of AgNPs without any harmful chemicals. The analytical results confirmed the presence of AgNPs without any contamination. The green synthesized AgNPs had a significant bactericidal property against phytopathogenic bacteria. The cytotoxicity of the synthesized AgNPs indicates that further studies are needed before using these nanoparticles in antimicrobial products.

\section{Acknowledgment}

This research was supported by Basic Science Research Program through the National Research Foundation of Korea (NRF) funded by the Ministry of Education, Science and Technology (2012R1A1A4A01011658).

\section{Disclosure}

The authors declare no conflict of interest in this work.

\section{References}

1. Raveendran P, Fu J, Wallen SL. Completely "green" synthesis and stabilization of metal nanoparticles. J Am Chem Soc. 2003;125: 13940-13941.

2. Prow T, Smith JN, Grebe R, et al. Construction, gene delivery, and expression of DNA tethered nanoparticle. Mol Vis. 2006;12:606-615.

3. Dubey SP, Lahtinen M, Sarkka H, Sillanpaa M. Bioprospective of Sorbus aucuparia leaf extract in development of silver and gold nanocolloids. Colloids Surf B Biointerfaces. 2010;80(1):26-33.

4. Huang H, Yang Y. Preparation of silver nanoparticles in inorganic clay suspensions. Compos Sci Technol. 2008;68:2948-2953.

5. Sastry M, Ahmad A, Khan MI, Kumar R. Biosynthesis of metal nanoparticles using fungi and actinomycete. Curr Sci. 2003;85:162-170.

6. Suman TY, Radhika Rajasree SR, Kanchana A, Beena E. Biosynthesis, characterization and cytotoxic effect of plant mediated silver nanoparticles using Morinda citrifolia root extract. Colloids Surf B Biointerfaces. 2013;106:74-78.

7. Govarthanan M, Selvankumar T, Manoharan K, et al. Biosynthesis and characterization of silver nanoparticles using panchakavya, an Indian traditional farming formulating agent. Int J Nanomedicine. 2014;9: 1593-1599.
8. Lee KJ, Park SH, Govarthanan M, et al. Synthesis of silver nanoparticles using cow milk and their antifungal activity against phytopathogens. Mater Lett. 2013;105:128-131.

9. Ananda Babu S, Gurumallesh Prabu S. Synthesis of AgNPs using the extract of Calotropis procera flower at room temperature. Mater Lett. 2011;65:1675-1677.

10. Otari SV, Patil RM, Nadaf NH, Ghosh SJ, Pawar SH. Green biosynthesis of silver nanoparticles from an actinobacteria Rhodococcus sp. Mater Lett. 2012;72:92-94.

11. Shanker SS, Rai A, Ahmed A, Sastry M. Rapid synthesis of Au, Ag, and bimetallic Au core-Ag shell nanoparticles using Neem (Azadirachta indica) leaf broth. J Colloid Interface Sci. 2004;275(2):496-502.

12. Ramteke C, Chakrabarti T, Sarangi BK, Pandey R-A. Synthesis of silver nanoparticles from the aqueous extract of leaves of Ocimum sanctum for enhanced antibacterial activity. $J$ Chem. 2013;2013:1-7.

13. Zayed MF, Eisa WH, Shabaka AA. Malya parviflora extract assisted green synthesis of silver nanoparticles. Spectrochim Acta A. 2012;98: 423-428.

14. Shankar S, Ahmad A, Sastry M. Geranium leaf assisted biosynthesis of silver nanoparticles. Biotechnol Prog. 2003;19(6):1627-1631.

15. Chandran SP, Chadudhary M, Pasricha R, Ahamad A, Sastry M. Synthesis of gold nanotriangles and silver nanoparticles using Aloe vera plant extract. Biotechnol Prog. 2006;22(2):577-583.

16. Pan L, Sinden MR, Kennedy AH, Chai H, Watson LE, Graham TL. Bioactive constituents of Helianthus tuberosus (Jerusalem artichoke). Phytochem Lett. 2009;2(1):15-18.

17. Talipova M. Lipids of Helianthus tuberosus L. Chem Nat Comp. 2001; 37(3):213-215.

18. Sukirtha R, Priyanka K, Antony JJ, et al. Cytotoxic effect of Green synthesized silver nanoparticles using Melia azedarach against in vitro HeLa cell lines and lymphoma mice model. Process Biochem. 2012; 47(2):273-279.

19. Miura N, Shinohara Y. Cytotoxic effect and apoptosis induction by silver nanoparticles in HeLa cells. Biochem Biophys Res Commun. 2009; 390:733-737.

20. Hsin YH, Chen CF, Huang S, Shih TS, Lai PS, Chueh PJ. The apoptotic effect of nanosilver is mediated by a ROS- and JNK-dependent mechanism involving the mitochondrial pathway in NIH3T3 cells. Toxicol Lett. 2008;179:130-139.

21. Asha Rani PV, Low Kah Mun G, Hande MP, Valiyaveettil S. Cytotoxicity and genotoxicity of silver nanoparticles in human cells. ACS Nano. 2009;3:279-290.

22. Vivek R, Thangam R, Muthuchelian K, Gunasekaran P, Kaveri K, Kannan S. Green biosynthesis of silver nanoparticles from Annona squamosa leaf extract and its in vitro cytotoxic effect on MCF-7 cells. Process Biochem. 2012;47:2405-2410.

23. Pelegrini PB, Noronha EF, Muniz MA, et al. An antifungal peptide from passion fruit (Passiflora edulis) seeds with similarities to $2 \mathrm{~S}$ albumin proteins. Biochim Biophys Acta. 2006;1764(6):1141-1146.

24. Lu L, Hsieh M, Oriss TB, et al. Generation of DC from mouse spleen cell cultures in response to GM-CSF: immunophenotypic and functional analyses. Immunology. 1995;84:127-134.

25. Vidhu VK, Aromal SS, Philip D. Green synthesis of silver nanoparticles using Macrotyloma uniorum. Spectrochim Acta A Mol Biomol Spectrosc. 2011;83:392-397.

26. Ashok Kumar D, Palanichamy V, Mohana Roopan S. Green synthesis of silver nanoparticles using Alternanthera dentata leaf extract at room temperature and their antimicrobial activity. Spectrochim Acta A Mol Biomol Spectrosc. 2014;127:168-171.

27. Shaligram NS, Bule M, Bhambure R, et al. Biosynthesis of silver nanoparticles using aqueous extract from the compactin producing fungal strain process. Process Biochem. 2009;44:939-943.

28. Balaji DS, Basavaraja S, Deshpande R, Mahesh DB, Prabhakar BK, Venkataraman A. Extracellular biosynthesis of functionalized silver nanoparticles by strains of Cladosporium cladosporioides fungus. Colloids Surf B Biointerfaces. 2009;68(1):88-92. 
29. Muniyappan N, Nagarajan NS. Green synthesis of silver nanoparticles with Dalbergia spinosa leaves and their applications in biological and catalytic activities. Process Biochem. 2014;49(6):1054-1061.

30. Hackenberg S, Scherzed A, Kessler M, et al. Silver nanoparticle: evaluation of DNA damage, toxicity and functional impairment in human mesenchymal stem cells. Toxicol Lett. 2011;201(1):27-33.

31. Jacob SJ, Finub JS, Narayanan A. Synthesis of silver nanoparticles using Piper longum leaf extracts and its cytotoxic activity against Hep-2 cell line. Colloids Surf B Biointerfaces. 2012;91:212-214.
32. Patel B, Shah VR, Bavadekar SA. Anti-proliferative effects of carvacrol on human prostate cancer cell line, LNCaP. FASEB J. 2012;26: 1037. 5 .

33. Sankar R, Karthik A, Prabu A, Karthik S, Shivashankari KS, Ravikumar V. Origanum vulgare mediated biosynthesis of silver nanoparticles for its antibacterial and anticancer activity. Colloids Surf B Biointerfaces. 2013;108:80-84.

\section{Publish your work in this journal}

The International Journal of Nanomedicine is an international, peerreviewed journal focusing on the application of nanotechnology in diagnostics, therapeutics, and drug delivery systems throughout the biomedical field. This journal is indexed on PubMed Central, MedLine, CAS, SciSearch ${ }^{\circledR}$, Current Contents ${ }^{\circledR} /$ Clinical Medicine,

\section{Dovepress}

Journal Citation Reports/Science Edition, EMBase, Scopus and the Elsevier Bibliographic databases. The manuscript management system is completely online and includes a very quick and fair peer-review system, which is all easy to use. Visit http://www.dovepress.com/ testimonials.php to read real quotes from published authors.

Submit your manuscript here: http://www.dovepress.com/international-journal-of-nanomedicine-journal 